\title{
Early Christian spirituality according to the First Epistle of John: The identification of different 'lived experiences'
}

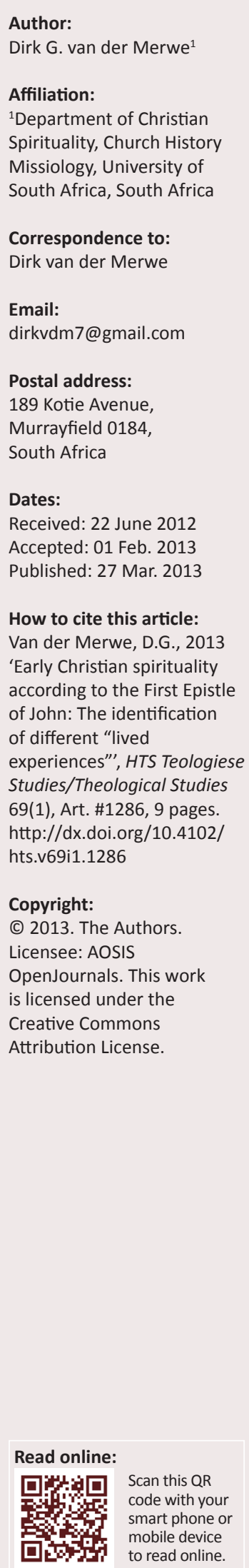

The interest in this article is early Christian spirituality. The word 'spirituality' is used here denoting 'a lived experience'. Therefore, the article focuses on religious experience in an early Christian community as explicated in the first chapter of the First Epistle of John. Three different lived experiences are denoted here, culminating in the last one: 'having fellowship with the divine'. The first two experiences (experience through physical senses, experience through spiritual senses) pave the way to establish fellowship with the divine. For the author of 1 John, the purpose (iv $\alpha$ ) of these lived experiences is to have (iv $\alpha$ ) complete joy, another form of experience. These three lived experiences express three different configurations of spirituality.

\section{Introduction}

From its beginnings, the study of the New Testament (NT) was concerned mainly about theology, mining the New Testament for what it has to say that would inform, support or challenge Christian beliefs. Scholarly traditions, the apparatus of scholarship and the questions and approaches all focused heavily on the religious thought of the New Testament and other early Christian texts. Unfortunately very little attention was given to the nature and importance of the religious experiences attested. Scholars who were more negatively or critically disposed to Christianity were usually uncomfortable with or uncertain about the whole idea of religious experience (cf. Hurtado 2003:65).

Most students of Christian origins will agree that Christianity goes back to certain deeply significant experiences of the first disciples - experiences in which they saw the 'incarnated' and 'resurrected' Jesus. This investigation will help better to understand the experiences and the faith which gave Christianity its distinctive character (cf. Dunn 1975:2). A sympathetic study of the language with which (Jesus and) the first Christians articulated their religious experience should therefore enable this research to gain some insight into the understanding and evaluation of their religious experiences. Obviously, religious experience is, as is commonly known, ambiguous. However, if the nature of the experience that caused first-generation Christians to refer to (God or the Spirit or) Jesus can be brought to light, an evaluation of their experience will become that much more feasible (Dunn 1975:3).

The interest and focus in this article is on religious experience in an early Christian community as explicated in the first chapter of the First Epistle of John. In this chapter, three different 'lived experiences' can be distinguished, which culminate ${ }^{1}$ in the last one: 'having fellowship with the divine' (1:3b). The first two experiences (experience through physical senses and experience through spiritual senses) pave the way to establish fellowship with the divine. For the author of 1 John (hereafter the Elder), these lived experiences must ultimately result in having 'complete joy'

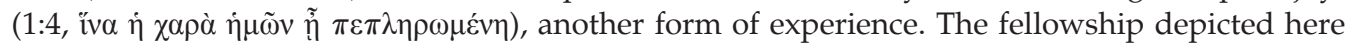
is emphasised (see chiasm in 1:3,6-7) and developed in the rest of 1 John 1 (and the Epistle) ${ }^{2}$ as 'walking in the light' and 'the experience of the forgiveness of sin'. This fellowship was important for the adherents of the Elder should not to lose faith.

The purpose of this article, then, is to point out that, although spirituality is dynamic in terms of lived experiences and numerous in expressions, it must be borne in mind that there are different configurations of lived experiences in the early Christian Johannine community. It will also be

\footnotetext{
1.The Elder elaborates more on the last one which is one of the main themes that runs throughout the Epistle. For Akin (2001:63), the ultimate purpose of the proclamation and writing of the Elder is that his readers may participate in the Christian (apostolic) fellowship (and joy) with the Father and his Son.

2.1 John 1:5-2:2 is the foundation of fellowship; $2: 3-11$ spells out the criterion for fellowship; $2: 12-17$ define the test for fellowship. The rest of the Epistle spells out some features of this fellowship: (1) fellowship as a matter of 'knowing', 'having', 'being in' and 'abiding in',

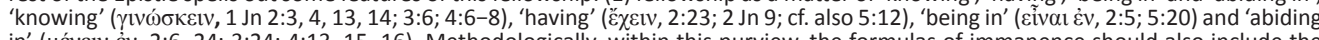
in' ( $\mu \varepsilon \dot{v \varepsilon} v \dot{\varepsilon} v, 2: 6,24 ; 3: 24 ; 4: 13,15,16)$. Methodologically, within this purview, the formulas of immanence should also include the 'abiding' in other entities which are also closely connected to God, such as 'truth' (1:8; 2:4; 2 Jn 2); 'his word' (1:19; 2:14; cf. 2:24; 5:10); his 'anointing' (2:27); 'his seed' (3:9); 'eternal life' (3:15); 'love' (4:12; cf. 2:5; 3:17); the Spirit (3:24; 4:13); God Himself (3:24[bis]) abiding in the believer and the abiding of the believer in the Son $(2: 6,24,28 ; 3: 5,24)$. Mutual abiding is referred to in $4: 13,15,16$ and in 2 John 9; (2) fellowship as a matter of acting ( $\pi \varepsilon p$ i $\pi \tau \varepsilon \varepsilon \tau v)$ according to one's immanency; (3) fellowship as a matter of Imitatio Christi: '... ought to walk just as' ( $\alpha \alpha \dot{\theta} \varsigma$ ) He walked (2:6) (see Van der Merwe 2006a:539-555).
} 
determined what kind of phenomena the Elder used in creating lived experiences by means of texts amongst his readers.

This presentation will start with a semantic analysis of 1 John 1:1-4 so that the indicated semantic network will help to constitute the structure of this article. The phenomenon of early Christian spirituality will then be explored from the perspective of three different lived experiences. For the Elder, such experiences must culminate in complete joy.

\section{Discourse analysis of 1 John 1:1-4}

\section{Analysis}

The following discourse analysis of 1 John 1:1-4 (Figure 1) will help to determine the structure of the text, the rhetorical account of argumentation and the focus areas in the text.

\section{Discussion of the above discourse analysis}

From the schematic discourse analysis (Figure 1), it is apparent that there are three sections $(\mathrm{A}-\mathrm{C})$ according to the linguistic relations. These three sections are semantically grouped together by virtue of the actants, 'we' and 'you', which occur consistently throughout the three sections (Du Rand 1981:3). It is clear that sections B and C are the objectives for the events spelled out in section $\mathrm{A}$, owing to the occurrence of the conjunction particle iv $\alpha$ [so that] in each section, which refers to intended results (Haas, De Jonge \& Swellengrebel 1972:28; see Du Rand 1981:3 for differences of the above analysis).

The focal point in section A (1:1-3a) is the announcement

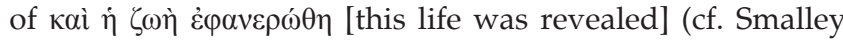
2002:9; Du Rand 1981:3). This is due to the fact that 1:1 ends and 1:2 starts with reference to $\dot{\eta} \zeta \omega \eta$ [the life], which also occurs three times in this section. Although the syntax of verses 1 and 2 'is a difficult complication because of the repetition of accumulative thoughts ${ }^{\prime 3}$ (Du Rand 1981:4),

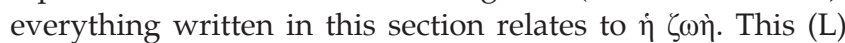

3.Dodd (1953:3) refers to it as a 'grammatical tangle'. Smalley (2002:5) describes it as a 'grammatically complicated sentence'.

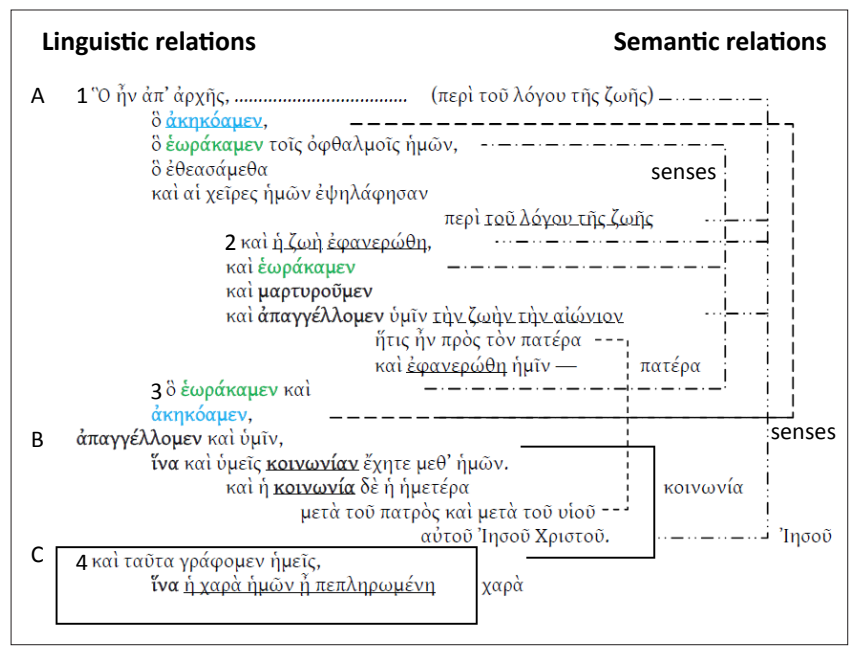

FIGURE 1: Discourse analysis of John 1:1-4. life has physically been revealed by the incarnation of God's Son $(4: 9,10,14)$. It has also been revealed spiritually by the understanding of perception that this Life was the eternal life that was with the Father (1:2), Jesus Christ, the Son of God.

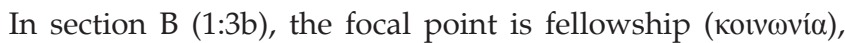
affirmed by the double extended iv $\alpha$ clause. What was

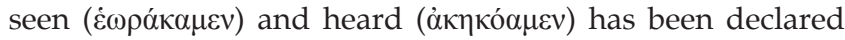
( $\dot{\alpha} \pi \alpha \gamma \gamma \varepsilon \dot{\varepsilon} \lambda \mathrm{O} \mu \mu \varepsilon$ ) by the Elder to his adherents 'so that' (iv $\alpha$ ) they could have fellowship with the Elder and his earlier followers, and with the Father and his Son. This relates semantically to the last part of 1:2.

In section C (1:4), the noun 'joy' ( $\chi \alpha \rho \dot{\alpha})$ is not a purpose in itself as in the case of the iv $\alpha$ clause in verse 3 , but it depends on the establishment of fellowship stated in verse 3.

Conclusion: The sentence that begins in 1:1 and is interrupted by the parenthesis of verse 2 resumes in verse 3 and concludes in verse 4 . The Elder recalls the sense experience of the authoritative message which he is 'proclaiming' to his readers; he announces his deeper insight into these events. He has discerned that the person they have seen, heard and touched is indisputably Jesus Christ, the Son of God, the eternal life. He also announces that its immediate purpose is fellowship (both human and divine, 1:3; see also 1:6,7) whilst its ultimate intention is joy (1:4).

Jesus Christ, the Son of God, the (L)life, ${ }^{4}$ accomplishes an important revelatory-salvific act so that believers can have fellowship with one another and with God (sections A-C). Such fellowship is one of the objectives stated for the proclamation of the gospel and is described by the symbolic narrative (environment) of family life ${ }^{5}$ where God is the Father and Jesus is his Son (section B). Finally the joy of believers in this familia Dei (family of God) only becomes complete where there is fellowship amongst one another and with God (section C). These thoughts will now be examined from the perspective of a lived experience.

\section{Early Christian spirituality}

Christian spirituality refers to the lived experience of Christian faith. ${ }^{6}$ In each book of the Bible, the spiritualities ${ }^{7}$ of the authors and the people referred to in these books are embedded and can be discovered through imaginative exegesis. ${ }^{8}$ Therefore, we can ascertain that the experiences

4.The term $\zeta \omega \eta$ [life] may refer to Jesus Himself (as in the Fourth Gospel; cf. In 11:25; 14:6) in which case the writer is claiming that 'Jesus was revealed'. Westcott (1982:8) points out that the term 'life' is not to be regarded as a personal name exactly equivalent to 'Jesus' or to $\lambda$ '́ $_{0} \varsigma \varsigma_{\text {[word] }}$ as used in association with Jesus (cf. In 1:14). Rather, 'life' expresses one aspect of His being and activity.

5.For a concise statement of the conventional ethical view on these verses, see Marshall (1978:110-12).

6.The intensity of the relationship between the Christian believer and the divine determines the nature and intensity of the spirituality of this person.

7.A varieties of spiritualities occur in the Bible: '... the dialogical spirituality of the deuteronomistic tradition in which God intervenes directly and participates in Israel's history, the profoundly Christocentric spirituality of Paul, the contemplative Jesus-centered spirituality of John, the ecclesiastical spirituality of the pastorals, the apocalyptic spirituality of Revelation. In the Psalms we find expressed in prayer and poetry the full range of Old Testament spiritualities that have been practiced by Christians in the light of the mystery of Christ' (Schneiders 2002:135). We can even add more to this.

8.See Lombaard (2008a:139-153) for a discussion on imaginative exegesis. 
incorporated in the books of the $\mathrm{NT}^{9}$ do not only reflect certain early Christian spiritualities but also evoke certain lived experiences amongst the readers. Their lived experiences cast the process and project of life integration in terms of the ultimate horizon and basic coordinates of Christian faith According to Schneiders (2002:134), the ultimate horizon of faith is God who has been revealed in Jesus Christ into whose divine life Christian believers are incorporated by the gift of the Spirit. The basic coordinates of the life of faith would be this early Christian believing Johannine community (i.e. the church) in which that faith was lived. Thus, Christian spirituality is a self-transcending faith in which union with God in Jesus Christ through the Spirit expresses itself in service of other members in the Johannine community and in participation in the realisation of the reign of God in this world. It is a transformative process of personal and communal engagement with the gospel message or biblical text. ${ }^{10}$ This is precisely the message of 1 John $1: 1-4$

Each author in the Bible wishes to evoke such a response from the readers. From the discourse analysis of 1 John 1, three different configurations ${ }^{11}$ of experience can be distinguished which should culminate in joy, according to the Elder: ${ }^{12}$

9.Earliest Christianity was characterised by a rich and varied assortment of religious experiences. According to Hurtado (2000:183; cf. also Schneiders 2002:134f.), these experiences could be found along a continuum which ranged from the quiet and inward to the dramatic and outward categories. During the previous centuries, studies were conducted that were concerned with exploring the nature of the religious experiences reflected in the New Testament. The publication of Die Wirkingen des Heiligen Geistes nach der popularen Anschauung der apostolischen
Wiration Zeit und der Lehre des Apostels Paulus: eine biblisch-theologische Studie by Zeit und der Lehre des Apostels Paulus: eine biblisch-theologische Studie by
Hermann Gunkel (1909) opened the interest of religious experience in the early Christian movement. During the second part of the previous century, a new interes in the study of religious experiences appeared alongside the growing Pentecostal and charismatic movements. The appearance in 1970 of the book Baptism in the Holy Spirit, by James Dunn, as well as his classic publication of Jesus and the Spirit in 1975 are clear examples of the renewed interest in religious experience. In the meantime, other valuable books on religious experience were published in due course (see the publications of Johnson [1998], Berger [2003] and Hurtado [2003] to name a few). Some scholars like Smith (1951 and 1978), Jackson (1988), Ehrmans (in his many publications), Nabarz (2005) and Graves (2007) sought to show that Christian beliefs and practices were very much shaped by and derived from nonChristian sources, in particular 'pagan' religious traditions, in order to argue against Christian sources, in particular 'pagan'
the continuing validity of those beliefs.

10. 'Spirituality ... points to those aspects of a person's living or commitment that concern his or her striving to attain the highest ideal or goal. For the Christian this would mean his or her striving for an ever more intense union with the Father through Jesus Christ by living in the Spirit' (Principe 2000:51).

11.In his investigation on the 'taxonomy of religious experience', Stark (1965:99) sketches four such possible configurations of interactor relations:

1. The human actor simply notes (feels, senses, etc.) the existence or presence of the divine actor.

2. Mutual presence is acknowledged; the divine actor is perceived as noting the presence of the human actor.

3. The awareness of mutual presence is replaced by an affective relationship akin to love or friendship.

4. The human actor perceives himself as a confidant of and/or a fellow participant in action with the divine actor.

These configurations of Stark on 'religious experience' correspond well with those configurations deduced from the text of 1 John 1:1-2:2. The last two configuration proposed by Stark can be accommodated in the last configuration of fellowship within the family. Stark then came to the conclusion that it can be 'suggested that this order represents a developmental model and that persons pass from the less complex to the more complex during the career of their religious encounters However, here one must also bear in mind the argument of Lombaard (2008b:98) that the 'biblical writers had themselves purposely intended to indicate to their readers these internal editorial, and therefore, debating activities. These are indeed deliberately 'writerly' texts, which both exhort and inform later, including indeed deliberately "writerly' texts, which both exhort and inform later, including modern, dialogue. ... The Bible contains different, overtly competing spiritualities. Contemporary research should investigate these and other potential configuration associated with the perception of religious experience. The extent to which types with reard with regard to such configurations as formal religious affiliation and depth of religious involvement. There would seem to be some consistency in continuing to use Stark's types as a framework for investigation, keeping in mind that they are not always and in all circumstances seen as distinct (cf. Burger \& Allen 1973:262).

12.Schneiders (2002:135) is certainly correct that we find in the Bible a variety of biblical spiritualities, a few of which she has named except $1 \mathrm{John}$. The spirituality in 1 John is fellowship-centred. In 1 John 1, the Elder explains how the Christian believer moves through three different configurations of spirituality to the lived
1. a physical configuration: a lived experience through physical senses ${ }^{13}$

2. a spiritual configuration: a lived experience through spiritual senses ${ }^{14}$

3. a corporate family configuration: a lived experience of God and his Son Jesus Christ through fellowship in the community. ${ }^{15}$

\section{A lived experience through physical senses (1:1-3)}

Kruse (2000:52) makes a valuable contribution to the semantics of the introductory verses (1:1-4). He points out that the first relative clause, 'what was from the beginning', is actually structured differently from the four succeeding (one in 1:3a) relative clauses. All five relative clauses are the

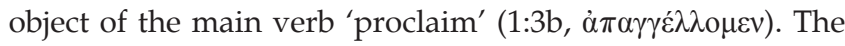
relative pronoun in the first relative clause is the subject of the verb 'to be' $(1: 1, \tilde{\eta} v)$ whereas the relative pronouns in the other four clauses are the objects of various verbs of sense perception (also Brown 1982:154; Bultmann 1973:7-8, n. 3). Besides this switch from subject to object within the relative clauses, the verb in the first relative clause ascribes what the Word of life is inherently. The verbs in the remaining four relative clauses describe the sense perception of others concerning the Word of life (i.e. we saw, heard, touched it). Most likely, the first relative clause is itself the antecedent of the following four relative pronouns. This then implies that he is a deity, who is from eternity, the one the Elder and his fellow apostolic eyewitnesses had seen and touched and proclaimed. The contrast in time frame between 'what was from the beginning' and 'what we have seen with our eyes $\ldots$ and our hands have touched' then indicates a contrast between eternity ${ }^{16}$ and a definite past event. In other words, the Elder and other eyewitnesses heard, saw, touched and experienced this deity, who has life in himself from eternity, incarnated in time and space and history. He is the eternal Son of God, Jesus the Christ who came in the flesh (cf. Jn 1:14; Kruse 2000:53).

The Word of life is, firstly, described as that 'which we

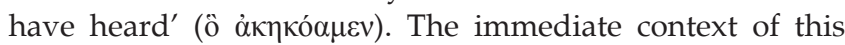
expression in 1:1 makes it clear that an actual first-hand hearing of the proclamation of Jesus is implied. The Word

(Footnote 12 continues ...)

experience to enjoy fellowship with the divine. These three configurations relate as follows to Schneiders's explanation of spirituality (2002:134): Ultimate horizon: (1) physical configuration: hear, see, experience the gospel (2) spiritual configuration: perception of Jesus' identity; Basic coordinates: (3) corporate family configuration: live the gospel.

13.This refers to the physical seeing and physical experience of the presence of something.

14.This refers to a deeper spiritual notion or insight of the identity of someone.

15.Although these experiences may share some aspects, the continuity of religious life is more like links in a chain which overlap, not a unique set of aspects common to all religious experiences (cf. Margolis \& Elifson 1979:67).

16.Scholars differ on the meaning of $\dot{\alpha} \pi$ ' $\alpha \rho \chi \tilde{\eta} \zeta$. Although contextual indicators restricting $\alpha \dot{\alpha} \alpha \rho \chi \tilde{\eta} \varsigma$ to a certain temporal point are absent, it can refer to 'a period before the creation of the world' (Thomas 2004:62) or the beginning of creation (Haas et al. 1994:11). It might refer to Jesus' eternal coexistence with the Father or to the beginning of creation (Gn 1:1; Jn 1:1), but in this context, John was probably referring to the beginning of Jesus' ministry (Walls \& Anders 1999:155) or eternity (cf. Delling 1979:481-82). Smalley (2002:7) interprets it as the 'beginning' of the (cf. Delling 1979:481-82). Smalley (2002.7) interprets it as the 'beginning' of the Kruse (2000:53) for a linguistic verification. 
of life that was heard is, secondly, described as that which

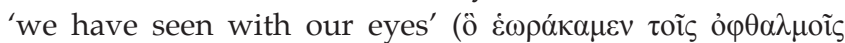
$\dot{\eta} \mu \tilde{\omega} v)$. This expression, found only here in the NT, is used to reinforce the claim that the proclamation of the Word of life comes from one who is an eyewitness. ${ }^{17}$ That which 'we have seen ...' implies first-hand sense perception. ${ }^{18}$ The Word of life is, thirdly, described as something which our hands have touched ( $\alpha i \chi \varepsilon \tilde{\varepsilon} \tilde{\rho} \varepsilon \varsigma \dot{\eta} \mu \tilde{\omega} \nu \dot{\varepsilon} \psi \eta \lambda \dot{\alpha} \varphi \eta \sigma \alpha v)$. In the present context, the Elder is clearly using the verb to mean physical touching with the hands. ${ }^{19}$ By doing so, he claims that his proclamation rests on the experience of not only seeing and hearing but also touching the Word of life with his own hands. This physical lived experience of seeing, hearing and touching makes an impact on the Elder's life.

This results in an excitement which the Elder experiences. This excitement is evident from the text, in the sense of repetition. Three times he refers to what they have heard ( $\dot{\alpha} \kappa \eta \kappa o ́ \alpha \mu \varepsilon v$,

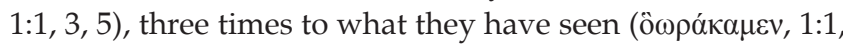
2, 3; cf. also $\theta \varepsilon \alpha \sigma \alpha \dot{\mu} \varepsilon \theta \alpha, 1)$ and once to what they have touched with their hands ( $\alpha i \chi \varepsilon \tilde{\imath} \rho \varepsilon \varsigma \dot{\eta} \mu \tilde{\omega} v \dot{\varepsilon} \psi \eta \lambda \alpha \dot{\alpha} \varphi \eta \sigma \alpha v, 1: 1$ ): Jesus Christ (1:3). He uses the forensic verb 'testify' ( $\mu \alpha \rho \tau$ once, but 'proclaim' ( $\alpha \pi \alpha \gamma \gamma \varepsilon \dot{\lambda} \lambda \lambda \mathrm{o} \mu \varepsilon v, 1: 2,3,5)^{21}$ also used three times. According to Danker (2000:95), $\dot{\alpha} \pi \alpha \gamma \gamma \varepsilon \dot{\lambda} \lambda$ o $\mu \varepsilon v$ means 'to make something known publicly, proclaim' (of something in the present...) and, according to Louw and Nida (1996:I, $410)$, to announce or inform, with possible focus upon the source of information. This excitement culminates in the

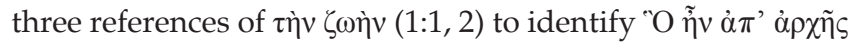
(1:1). Everything written in section A relates to $\dot{\eta} \zeta \omega \grave{\eta}$.

Through his preaching, the Elder evokes lived experiences for his readers. ${ }^{22}$ They have to experience the Word of life or Eternal life. Those who hear this proclamation, experience

17.The Elder emphasises his status as one of those who actually saw with his eyes the Word of life by using a perfect form (ö $\dot{\varepsilon} \omega \rho \alpha \dot{\alpha} \alpha \alpha \mu \varepsilon v$ ) of the verb 'to see' here.

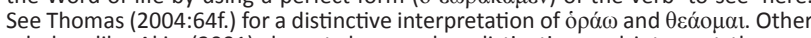
scholars like Akin (2001) do not draw such a distinction and interpret them as scholars like Akin (2001) do not draw such a distinction and interpret them as
synonyms (Smalley 2002). For Haas et al. (1994:12) this variation seems to be for synonyms (Smalley 2002). For Haas et al.
stylistic rather than for semantic reasons.

18.This is supported by the fact that all but one of the 91 uses of expressions combining forms of the verb 'to see' and the words 'with the eyes' in the LXX imply sense perception, that is, a direct personal acquaintance with the object said to have been seen. The Word of life is described as that which we have looked at ( 0

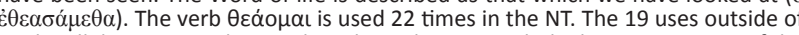
$1 \mathrm{John}$ all denote unambiguously a physical seeing with the human eye. One of the three uses in 1 John (4:12: 'no one has ever seen God') also relates unambiguously to seeing with the human eye. There is little reason, therefore, to think that the other two uses in 1 John, found here in 1:1 and in 4:14 (in both places the author claims to be amongst those who saw the Word of life or the Son) should be understood in any way other than actually physically seeing with the human eye. understood in any way other than actually physically seeing with the human eye. There does not appear to be any notable difference in meaning between the verb

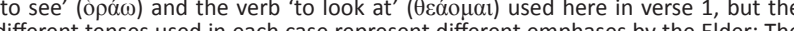
different tenses used in each case represent different emphases by the Elder: The Elder as one of the eyewitnesses, and the aorist (in the case of 'we have looked at') simply narrates the seeing itself.

19.The expression 'to touch with the hands' is found only here in the NT, but the verb 'to touch' ( $\psi \eta \lambda \alpha \varphi \alpha ́ \omega)$ occurs in three other places: in Luke 24:39 and Hebrews $12: 18$, where it denotes a physical touching (with the hands), and in Acts 17:27, where it has the metaphorical sense of feeling after God (something made clear by the context). The verb is found 15 times in the LXX, where it is used predominantly to denote actual touching (with the hands).

20.Used here to communicate objective information.

21.The verb $\alpha \dot{\alpha} \alpha \gamma \gamma \varepsilon \dot{\varepsilon} \lambda \lambda_{0} \mu \varepsilon v$ ['we are declaring'] in verses 2 and 3 is picked up here by the similar verb $\alpha \dot{v} \alpha \gamma \gamma \dot{\varepsilon} \lambda \lambda \lambda_{0} \mu \varepsilon v$ ['we are proclaiming'] (Smalley 2002:19). It is used here to communicate subjective information.

22.Later on during the history of the church, more lived experiences have been experienced through the 'transformative reading of Scripture' (cf. also Schneiders 2002:137-140). (see, hear, touch) Him in their minds, thoughts and feelings. According to Acts of the Apostles, the lives of those who did this preaching were transformed (e.g. Ac 2:37-41; 8:26-39). Through their experience of this person, the Elder and others interpret his appearance. The reiteration in 1:2 that they have seen him and the addition 'we testify to it and we proclaim to you the eternal life, which was with the Father' are emphasised by the Elder, and it evokes truthfulness. ${ }^{23}$

\section{Experience through spiritual senses (1:2)}

Therefore, from the foregoing, when the Elder says 'we proclaim' concerning the Word of life, he has in mind something much more than a spoken message. ${ }^{24}$ He proclaims the Word of life which he has heard, seen and touched. As will become clear in what follows, he proclaims a message ${ }^{25}$ that has been embodied and personalised - the person of Jesus Christ, the Son of God (cf. Kruse 2000:54).

The second configuration of spirituality, as depicted from the selected text, is the lived experience through spiritual senses. It is only when people have encountered Jesus Christ physically or through the hearing of the Gospel and consequently perceive the otherness and identity of this person (to be the Son of God or the Word of life) ${ }^{26}$ that a new and different lived experience emerges. Christian spirituality is not simply to encounter an amorphous personal God but represents more specifically the revelation of God manifested

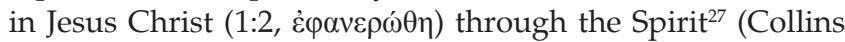
2000:13).

In 1:2, the Elder adds a new perspective which verifies the first statement by stating 'we proclaim to you the eternal life, which was with the Father'. This reference to 'eternal life

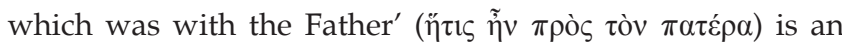
allusion to the teaching found in the prologue of the Fourth Gospel (1:2). ${ }^{28}$ There the Logos is described as the one who

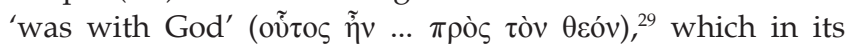
context means being in the closest relationship with Him (cf. Jn 1:1, 18). Therefore the Elder could state in 2:23: 'No one who denies the Son has the Father. He who confesses the Son has the Father also.'

The expression 'eternal life' here, then, does not denote an impersonal quality of life that comes from the Father. It actually refers to the Word of life, the Son of God, who was with the Father prior to his incarnation and in whom eternal

23.Speech act theory can also be implemented here very usefully.

24.Grayston (1975:279) contends that 1 John does not say that the $\lambda$ ó $\gamma_{0} \varsigma$ was from the beginning, and the beginning in 1 John is not necessarily the realm of the eternal. In 1 John, it is the life, not the $\lambda$ ó $\gamma o \zeta$, which is $\pi \rho$ ò $\varsigma$ the Father.

25.In her discussion of 'five ways of transformative reading of scripture', Schneiders (2002:137) mentions that historically, 'the first engagement of prospective Christians with the gospel was through hearing the preaching of the Word'.

26.According to Akin (2001:54), the following references refer to the same person: 'That which was from the beginning', who is 'the Word of life', is also 'the eternal life, which was with the Father'.

27. The Spirit of God is not explicitly referred to here, though it is implied by virtue of $4: 2$ and $5: 7$.

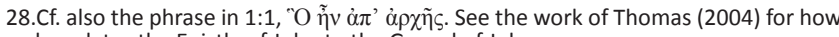
he relates the Epistle of John to the Gospel of John.

29.See also page 20 note 66 . 
life is found (cf. 1 Jn 5:11-12). It was the eternal life which was with God from the beginning and which, the Elder says, has appeared to us incarnate in Jesus Christ (Kruse 2000:57).

The object of proclamation then favours a reference to the pre-incarnate $\mathrm{Christ}^{30}$ rather than the 'gospel'. The most important evidence for this view is that the Elder vividly describes perceiving this object with his senses in a way that goes beyond the mere reception of a message, that is, 'we have seen with our eyes', 'we looked at' and 'our hands have touched'. ${ }^{31}$ The reason why the Elder uses the relative pronoun 'what or which' to begin his Epistle (1:1) is to draw equal attention to both the Word proclaimed and the Word as person. These two cannot be separated. Each explains and complements the other. The message about Jesus is intimately related to who Jesus is.

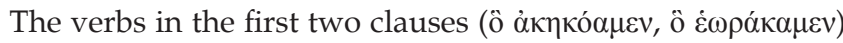
are significant, since hearing and especially sight are ideas which are close to faith in the Fourth Gospel (cf. Jn 10:27; 20:29; see further Smalley 1978:139-140; Thomas 2004:62-64). In this verse, a similar ambivalence may be associated with $\dot{\alpha} \kappa \eta \kappa o ́ \alpha \mu \varepsilon v$ and $\dot{\varepsilon} \omega \rho \alpha ́ \kappa \alpha \mu \varepsilon v$. John may thus be saying that the truths which prepared the way for the gospel were finally realised in Jesus (cf. Heb 1:1-2) when the Word of life could be heard in his preaching and seen in his ministry by those who believed (Smalley 2002:8). ${ }^{32}$

This reality and manifestation of God is experienced through the human senses in the transformative existential encounter with Jesus. ${ }^{33}$ 'From the record of these first adventures in Christian mission, we learn something important about biblical spirituality as preaching' (Schneiders 2002:137) and hearing and seeing.

In 1 John 1:2, it is clear that the Word of life refers to the person of Jesus, for here Jesus is substituted by 'the Life' ( $\dot{\eta}$ $\zeta \omega \eta \grave{)} \cdot{ }^{34}$ After their physical experience of Jesus, they come to a further spiritual experience of him. Now they experience him as the Word of life, eternal life and the Son of God. This lived experience lets them experience the divine, the new life in God. This new life is what the Elder is proclaiming new and what he wants his adherents to share with him. This sharing comes only through fellowship (in the family of God).

\section{For Akin (2001:54), the object of the proclamation is Christ, the Word of life.}

31.This argument was vital for Marshall (1978:101), Weir (1975:118-120) and Grayston (1975:279).

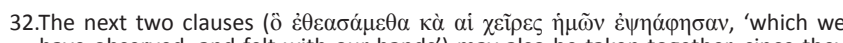
have observed, and felt with our hands') may also be taken together, since they balance the previous pair. The use of the verb $\theta \varepsilon \alpha \dot{\alpha} о \mu \alpha \mathrm{l}$ (ö $\dot{\varepsilon} \theta \varepsilon \alpha \sigma \alpha \dot{\alpha} \mu \varepsilon \theta \alpha$, 'which we

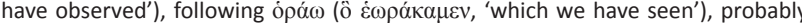
represents a literary variation (Schnackenburg 1992:60; also Haas et al. 1994:12), rather than a difference in meaning (Thomas 2004:63). In either case, the write rather than a difference in meaning (Thomas 2004:63). In either case, the writer (the incarnate Word was visible) and faith (we are called to believe in him) (Smalley 2002:8).

33.Today transformative engagement with the text comes through imaginative exegesis (experience)

34.Synonyms in this passage for the Word of life are eternal life (1:2), Jesus Christ his Son (1:3), blood of Jesus his Son (1:7) and paraclete (2:1).

\section{Experience through family life $(1: 3,6-7)$}

\section{Family dynamics in the first Epistle of John ${ }^{35}$}

In 1 John 1:2, 3, there are references to God as Father ( $\pi \alpha \tau \eta \dot{\rho})$

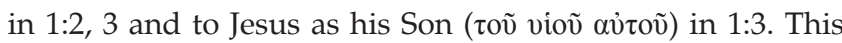
is familial terminology which is further enhanced by the

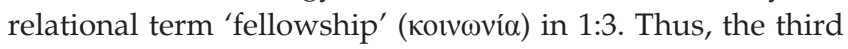
configuration of spirituality in this context is that the Elder portrays the Christian life in the Johannine community as existence in a family ${ }^{36}$, the familia Dei, ${ }^{37}$ where God is the Father $(1: 2,3)^{38}$ and the head. Jesus is the only Son of the Father $(4: 9)^{39}$ and the believers are 'children of God' ( $\tau \dot{\varepsilon} \kappa v \alpha$

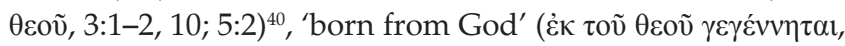
$2: 29 ; 3: 9 ; 4: 7 ; 5: 1,4,18)^{41}$. In 1 John, the followers of the Elder are also repeatedly addressed as 'little children' (Teкví $\alpha, 2: 1$,

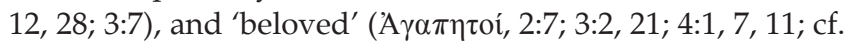
3 Jn 1, 2, 5, 11). They confess that God is 'Father' ( $\pi \alpha \tau \dot{\eta} \rho, 1: 2$; 2:1, 14-15, 22-24; 3:1; cf. also 2 Jn 4) and are referred to by the Elder as 'brothers' ( $\dot{\alpha} \delta \varepsilon \lambda \varphi o i$, 3:13) to one another. ${ }^{42}$ Then to become a member of this family, one has to be born ${ }^{43}$ into it. The Father gives the believers eternal life, enabling them to become part of this new family $(1: 13 ; 6: 4) .{ }^{44}$ Jesus is the

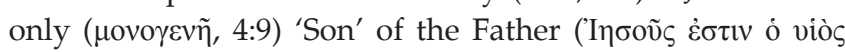

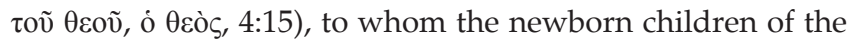
Father must adapt their lives (see the $\kappa \alpha \theta \omega) \varsigma$ expression in 2:6). Although there is no direct reference to the Spirit of God

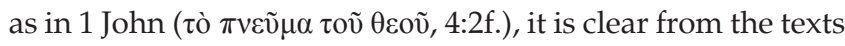
of reference that it is the Spirit of God (4:2; cf. also 3:24; 4:13) that constitutes the presence of the Father and guides and educates his children (1 Jn 2:27) in the familia Dei. By doing this, the Elder brings the Father, Jesus, the Holy Spirit and the believers into fellowship like that of an extended earthly family (cf. Tollefson 1999:88). Thus, the use of certain familial words creates experiences and can motivate people to act in a certain way. This can be verified by the work done by Osborn in his research on archetypal metaphor.

\section{Archetypal metaphor and spirituality}

Osborn (1967:115), in his research on archetypal metaphor in rhetoric, opens up important new lines for spirituality as a lived experience. His view of archetypal metaphor 'carries 35.See also Van der Merwe (2009:89-108).

36.Van der Watt (2000:157, 161-394), Thompson (2001:57-100), cf. also Rusam (1993:105ff.), Van der Watt (1999:494ff.), Van der Merwe (2005:443f.).

37. Esler (2000:148) points out that neither in Greek nor in Latin was there even a word that corresponded to our word 'family', although oikos in Greek and domus in Latin refer to the house and the household. This concept is also found in Galatians and 1 Thessalonians in the New Testament (Esler 1997:121ff.; 2000:145ff.). In the Old Testament, the term 'bêth' or 'house', like the word 'family' in modern languages, is flexible and may even include the entire nation ('house of Jacob' or the 'house of Israel') or a considerable section of the people (the 'house of Joseph' or the 'house of Judah'). It may denote kinship in the wide sense (De Vaux 1973:20).

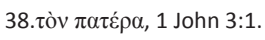

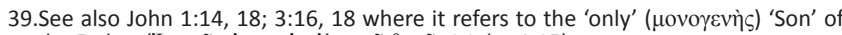

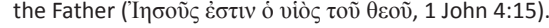

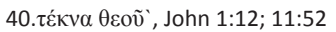

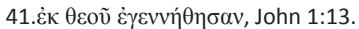

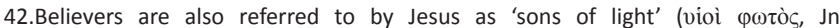
12:36).

43.See John 3:3-7 and Van der Watt (2000:162, 165-200, 398-400).

44.Also 1 John 2:25; 3:14-15; 5:11-13; 5:26. 
the idea of basic, unchanging patterns of experience'. Osborn (1967) claims that archetypal metaphors exhibit a persuasive potency because of their attachment to basic motives:

Because of certain universalities of appeal provided by their attachment to basic commonly shared motives, the speaker can expect such metaphors to touch the greater part of his audience. Arising from fundamental interests of men, they in turn activate basic motivational energies within audiences, and if successful, turn such energies into powerful currents running in favour of the speaker's recommendations. (p. 116)

In his study, Osborn focuses mostly on naturalistic archetypes and the metaphoric force they generate. The metaphoric images that Osborn worked on 'all derive their persuasive power from the power of the natural physical forces they invoke by comparison to significant social situations' (see also Adams 1983:56). ${ }^{45}$

In this research, the focus falls on the family image as archetype. ${ }^{46}$ The family is a relational image which gathers its archetypal force from the time and traditions surrounding the cultural construct of family. The family seems to be one of the oldest and most primary entities of social cohesion. It reaches back to the beginning of civilisation. Human beings have been united in the family experience for as long as human existence. Hence, Adams (1983) indicates that familial images derived from a:

common place and literal associations between human beings. They are the simple states of familial relatedness that we pass through as members of the social matrix, where conjoinment with others is the source of procreation and culture, and the creative grounding of our existence. To be related in family is the archetypal emphasis of humanity. (p. 56)

Thus, just as naturalistic metaphors have an impact upon people, so will this relational image have an impact on the children of God. Family bonds are made explicit by the Elder in his use of selected words, analogies or comparisons that denote or connote familial states amongst his readers. The use of relational images entangles the Elder and his adherents in relationships with the divine that have a priori behavioural expectations and lived experiences built into them. This suggests that familial images in written communication can be effective in evoking primary actions, attitudes and emotions (lived experiences) of the divine (the Father and his Son). By using familial terms, the Elder involves personal cognitive and emotional attachments that exist in early life within the

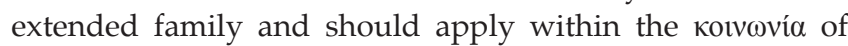
the children of God, the Son of God and the Father. These expectations are stored in the archetypal relational pattern as it has been played out through centuries of human situations (Adams 1983:56).

45.Osborn (1967:117) indicates that "light relates to the fundamental struggle for survival and development because of its relationship to warmth, sight, growth, etc'. 'The antithesis of light is darkness. If a rhetor can metaphorically relate light associations to certain people or propositions, and in turn relate dark association to opponents or opposing arguments, then the rhetor can effectively arouse feelings that are generally related to the image of the fundamental struggle between life and death symbolised by light and darkness' (Adams 1983.56). In such between life and death symbolised by light and darkness' (Adams 1983:56). In such a way, according to Osborn, the rhetor can deepen the urgency of the situation and magnify the importance of a conflict. The symbolic triumph of life (light) ove death (darkness) deepens the sense of satisfaction and commitment towards the good and darkness to what is evil, two metaphors also used in 1 John by the Elder.

46.On this archetype of family I rely strongly on the work done by Adams.
When the Elder tries to get his adherents imaginatively bonded-in-family, he exhibits a collective orientation. This is important because considerable discourse is designed to bond people for collective efforts and or distinguish them from other different groups. In such an experience, the Elder has at his disposal a range (or network) of familial images that can be conjured for collective purposes. It is the familial entanglement of his adherents that brings about a unity of purpose spelled out by the cultural or religious norms surrounding the particular relationship. In this sense, relational images have a 'bonding power' that differs from other references of categorisation (Adams 1983:56f.).

This explanation convincingly highlights the strong rhetorical dynamic of the family metaphor with regard to spirituality. When it is applied in a specific situation to a certain group of people, it generates bonding and experiential powers which unite these people into a coherent group. This brings us to the point where we reflect on the familia Dei in 1 John with regard to using family metaphorics as a lived experience. This lived experience is further defined by the Elder as fellowship.

\section{Fellowship in the family ${ }^{47}$}

Existence in this familia Dei consists of lived experiences of fellowship ${ }^{48}$ with other members of this familia Dei. The

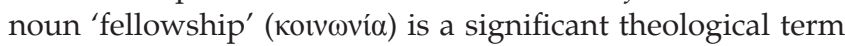
in 1 John, ${ }^{49}$ which occurs twice in the prologue (1:3bis) and twice in the rest of chapter one $(1: 6,7)$ to create a chiastic pattern. The function of the chiastic structure is to emphasise the interrelatedness and interdependency of the fellowship amongst believers ${ }^{50}$ and their corporate fellowship with God. One kind of fellowship demands and constitutes the other. ${ }^{51}$

The noun 'fellowship' denotes the active participation or sharing in what one has in common with others: Doing something together or sharing something (Haas et al. 1972:27). Thus a lived experience becomes a shared experience and a shared experience a lived experience. The nature of what is mutually shared shapes the character of the group. In this context, it refers to the lived experience of the 'new life' (cf. $1: 1,2 ; 2: 25 ; 5: 11-13)$ the believers share with Christ and God, and with one another. This new life in the Family (and in

47.Although the working definition for spirituality has been given in this article as a lived experience, such an experience can be either singular or, as referred to in 1 John, communal or corporative.

48.Alongside 'to have fellowship with God', which is only found in 1:3 and 6, one of the most common phrases is 'to be in God' (ö $\tau 1 \dot{\varepsilon} v \alpha v i \tilde{\omega} \dot{\varepsilon} \sigma \mu \varepsilon v, 2: 5 ; 5: 20$ ) or 'to abide' ( $\mu \varepsilon \dot{\varepsilon \varepsilon} v v, 2: 6,24 ; 3: 24 ; 4: 13,15,16)$. This combination with the typical word $\mu \varepsilon ́ v \varepsilon v$ is usually expanded (except in $2: 6,24$ ) into a twofold or reciprocal formula

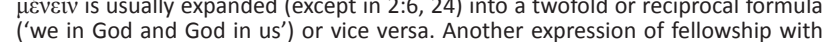

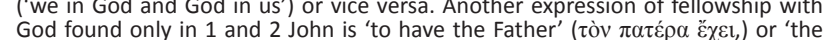

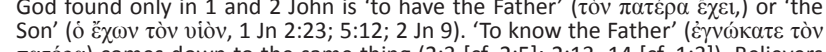
$\pi \alpha \tau \dot{\varepsilon} \rho \alpha)$ comes down to the same thing (2:3 [cf. 2:5]; 2:13, 14 [cf. 1:3]). Believers

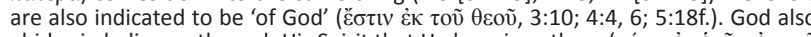

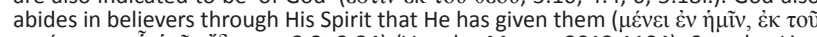
$\pi v \varepsilon v ́ \mu \alpha \tau o \zeta$ oṽ $\dot{\eta} \mu \mathrm{ĩ} v \tilde{\varepsilon} \delta \omega \kappa \varepsilon v, 2: 3 ; 3: 24)$ (Van der Merwe 2012:1104). See also Lieu (1991:31-48); Schnackenburg (1992:190f.).

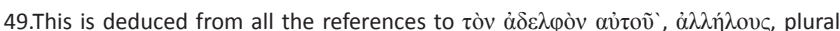
personal pronouns and verbs in the second personal plural.

50.One must distinguish here between the different constituents for fellowship between verse 3 and verses $6-7$.

51.The Greek word 'fellowship' lexicographically means, according to Danker (2000:552), 'close association involving mutual interests and sharing, association, communion, fellowship, close relationship'. The semantic meaning, according to Louw and Nida (1996:446), relates to Danker's definition: 'an association involving close mutual relations and involvement - "close association, fellowship".' 
Christ) creates and stimulates the desire for such fellowship and calls for active participation with other believers in this

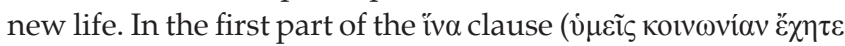
$\left.\mu \varepsilon \theta^{\prime} \dot{\eta} \mu \tilde{\omega} v\right)$ the Elder speaks of fellowship amongst Christians: a sharing which exists at the human level, even if it derives from a mutual indwelling in Christ. In the extended part of

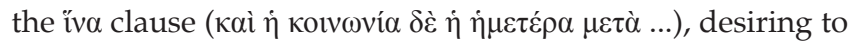
encourage and advance this Christian fellowship, the Elder describes the nature of Christian fellowship in terms of its divine origin and operation: 'and indeed our fellowship is

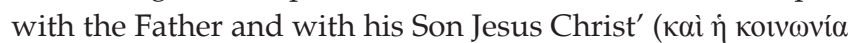

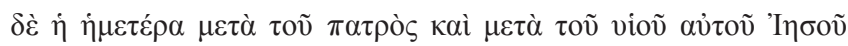

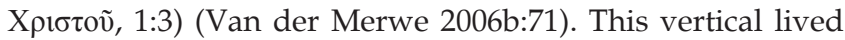
experience of fellowship is essential for true horizontal fellowship. The Elder makes the primary reference of

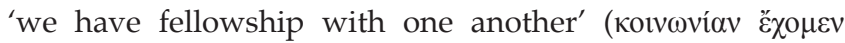
$\mu \varepsilon \tau$ ' $\dot{\alpha} \lambda \lambda \dot{\eta} \lambda \omega v, 1: 7)$ and this is dependent on 'you may have

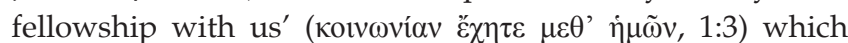
opens up the third lived experience of fellowship with the Father and his Son Jesus Christ (cf. Painter 2002:128; Rusam 1993:182; Westcott 1982:11). Thus, for the Elder it is axiomatic that fellowship with God involves fellowship with his people (Smalley 2002:24). In this instance, the noun 'fellowship' is used in a familial (metaphoric) sense. God is the Father, and the believers are brothers and sisters to one another. This lived experience of fellowship within the family is thus possible only between Father and children (cf. 1:3, 6).

Smalley (2002:12) points out that the practical dimension of the Elder's theology is evident here, as elsewhere in his Epistle. Knowledge and a faith perception of Jesus (see $1: 1,2,3 a$ ) are to be followed by action (cf. 2:3). Here, the lived experience of seeing, hearing and touching Christ is a declaration about him (1:2-3), and an invitation to have fellowship in him. Christian fellowship then refers to a relationship of those who mutually remain - 'in Christ' and therefore belong to one another (cf. 3:23-24).

Just how deep this lived experience of fellowship can be is indicated by the Greek linguistics in verse 3. The Elder uses

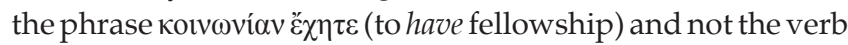

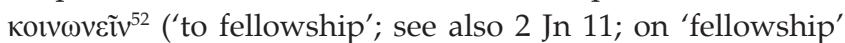

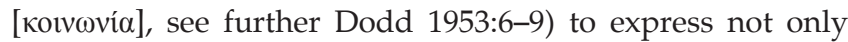
the fact but also the conscious experience and enjoyment of fellowship in Christ. The preposition $\mu \varepsilon \tau \alpha$ ( $\mu \varepsilon \theta$ ' $\dot{\eta} \mu \tilde{\omega} v$, 'with us') emphasises the deeply reciprocal spiritual relationship that can exist between one Christian and another. The verb ¿̌ $\chi \eta \tau \varepsilon$ (literally, 'you may have') in the present tense indicates that this relationship ought to be a continuous act (may share continuously).

In conclusion, the reference to Jesus, implicit from verse 1 onward, is specified here in verse 3. A high Christology is present in the latter part of verse 3. Jesus is regarded as one (in being and function) with the Father so that the lived

52.Although Painter (2002:122) points out that the usage of है $\chi \eta \tau$ is characteristic of the Elder, it still does not change its function, as pointed out, in this context. experience of fellowship with the Father and participation in his Son Jesus Christ are treated as parallel and synonymous

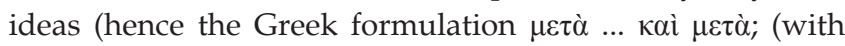
... and with). As Jesus revealed God, moreover (1:1-3), so he made the lived experience of fellowship with the Father finally possible.

Christian fellowship is essentially a lived experience of and a sharing experience 'with the Father, and with His Son

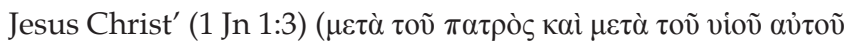
'I was initiated in verse 1 and developed in verse 2 reaches its conclusion in verse 3 . It is possible, the Elder claims, to receive eternal life and be in communion with its source because the Incarnation has taken place: 'the life was revealed' ( $\dot{\eta}$

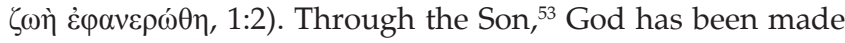
known and experienced as Father. Moreover, the knowledge of God, revealed through the Incarnation of Jesus (cf. Jn 17:3), is the common basis for both ideas of fellowship described in this verse, the human and divine.

\section{'... so that our joy may be complete' (1:4)}

Already as early as 1:3b and 1:4, the Elder pointed out his purpose for writing these things ( $\tau \alpha \tilde{\tau} \tau \alpha)$. The message, rather than the messenger, is highlighted in the main clause: ${ }^{54}$ 'these

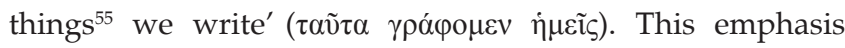
(cf. Walls \& Anders 1999:14) is the clue that we should not take the purpose of the Elder's writing to be his joy alone. Moreover, the parallel structure of $1: 3 \mathrm{~b}$ and 1:4, both with a purpose clause introduced by 'that' (iv $\alpha$ ), suggests that what is being proclaimed (1:3b) and written (1:4) is the same message. The message proclaimed by both the Elder and the apostolic witness to the original readers in the past and the continuing proclamation to them ${ }^{56}$ now is the same message ('these things') that he was (Akin 2001:60) proclaiming to them in the process of writing this Epistle. ${ }^{57}$ For the Elder, the purpose of the proclamation was that his readers may have fellowship with him and the apostolic witnesses. Since this oneness in community is presumably mutual, the joy is likely

53.The choice of 'Son' as a title for Jesus is no doubt influenced by the use of 'Father' as a designation for God (cf. 1:2; also 2:22-24). Both terms reflect the distinctive Father-Son relationship between God and Jesus which is characterised by the Fourth Evangelist (Jn 5:21-27; 10:36, 17:1; cf. further Smalley 2002:13).

54.The pronoun $\tau \alpha \tilde{\tau} \tau \alpha$ is placed in front of $\gamma \rho \alpha \dot{\alpha} \varphi \rho \mu \varepsilon v$

55. Uncertainty occurs amongst scholars with regard to the meaning of 'these things' ( $\tau \alpha \tilde{v} \tau \alpha)$. For Kruse (2000:59), it refers to the origins of the gospel, for Akin (2001:59) only to the eyewitness testimony to the incarnate Son of God mentioned in 1:1-3. It is disputed whether it refers to what precedes or what follows (see Schnackenburg is disputed whether it refers to what precedes or what follows (see Schnackenburg
1972:62, n. 43). According to Walls-Anders (1999:156) and also Haas et al. $1972: 62, \mathrm{n} .43)$. According to Walls-Anders (1999:156) and also Haas et al.
$(1972: 28)$, this refers to the message of the letter as a whole. The repetition of the $(1972: 28)$, this refers to the message of the letter as a whole. The repetition of the
verb 'write' ( $\gamma \rho \alpha \dot{\alpha} \varphi \omega, 1 \mathrm{Jn} 2: 1,7,8,12,13,14,21,26 ; 5: 13)$ seems to be clear in that verb 'write' ( $\gamma \rho \alpha \dot{\alpha} \varphi \omega, 1 \mathrm{Jn} 2: 1,7,8,12,13,14,21,26 ; 5: 13)$ seems to be clear in that
the Elder was in the process of writing and proclaiming this message. Since the rest of the Epistle expands upon the content of this message introduced in 1:1-3, the message to which 'these things' refers actually encompasses the message of the entire Epistle. This point of view is also accepted in this article.

56.The original readers were believers (e.g. 5:13) and had presumably been converted from hearing the Elder or had received the apostolic witness through others (1:5 suggests that the apostolic witness has not changed - 'we have heard from him and proclaim to you', 1:5.

57.The pronoun $\tau \alpha \tilde{v} \tau \alpha(1: 4)$ refers to the content of 1 John as a whole (cf. also Haas et al. 1972:28). In 1:1-3, the Elder has described the Christian proclamation about Jesus as the embodiment of the Word of life. This is now being expressed in

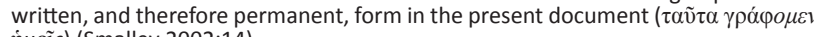

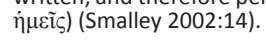


mutual as well: your joy as well as ours. ${ }^{58}$ For the Elder, these lived experiences should culminate in experiencing joy. The readers should share and experience the joy which the Elder

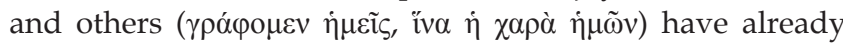
experienced. Their joy lies in the lived experience of seeing, hearing and touching Jesus, the Son of God. The readers must now share in these experiences and consequently their joy.

Returning to the context of 1 John 1:1-4, it is the joy that results from fellowship with the apostolic witnesses and with the Father and with the Son. ${ }^{59}$ Consequently, this fulfilment ${ }^{60}$ of joy is enjoyed during the church's earthly sojourn through the lived experience of faith in Christ, even though the full experience of it must await Christ's return and the consummation of all things. ${ }^{61}$ In effect, the Elder's purpose to achieve the fulfilment of his and his readers' joy (1:4) is one and the same as his purpose to keep his readers in fellowship with him and the other apostolic eyewitnesses (1:3) (Akin 2001:61).

\section{Conclusion}

During the past few decades, a paradigm shift has taken place from a general approach to theology towards a greater reflection on human experience as an authentic source of divine revelation. This brought about substantial changes in the way the Christian life has been studied. The studied concept of spiritual theology made way for a more fluid spirituality. Spirituality became more of a dialectic tension. On the one hand, there is the historical concreteness of revelation in Jesus and subsequent Christian tradition. On the other hand, there is the personal assimilation of salvation in Christ by each person within changing historical, cultural and social circumstances that demand new approaches to Christian conduct (Scheldrake 2000:22).

This research started off with a discourse analysis which contributed, through the semantic relations indicated, to structure the flow of this research. From the text analysis, three configurations of spirituality became evident. During the time of Jesus' ministry, the physical seeing, hearing and touching of Jesus created a specific 'lived experience' of him (e.g. his teaching in parables and his performance of miracles). That is what the Elder tries to communicate when he refers three times $(1: 1-3)$ to the physical experience

58.The nature of this joy ( $\chi \alpha \rho \alpha)$ to which the Elder refers parallels almost certainly in wording to Jesus' words in John 15:11 and 16:24. In those contexts, the lived experience of jes:61) Christ (Jn 政 abundance (Jn 15:8) (cf. Carson 1991:546). This bearing of fruit is defined in term of keeping Christ's commandments, defined as loving one another just as Christ oved them (culminating in laying down his life for them; In 15:10, 12-13). This joy is nothing less than the joy that comes from abiding in Christ's love, just as Christ's joy came from abiding in the Father's love (Jn 15:9-11).

59.Smalley (2002:15) notes that 'fullness of joy' is 'a familiar idea in the Johannine literature (cf. Jn 3:29; 4:36; 15:11; 16:24; 17:13; see also 2 Jn 12) where it is regularly associated with the notion of fellowship with God or with other believers' This fellowship is maintained by keeping God's commandments (cf. 'abides in him' in $1 \mathrm{Jn}$ 3:24), which is defined in $1 \mathrm{John}$ 3:23: 'And this is his commandment, that we believe in the name of his Son Jesus Christ, and love one another, just as he commanded us.'

60.The passive verb, 'fulfilled' or 'be filled', underlies the fact that God completes this joy (cf. also Rm 12:2; Eph 5:18).

61.It is best to see this joy as fulfilled in the present reality of fellowship with the Father, his Son, and other believers (cf. Jn 16:22ff.; so Schnackenburg 1972:63). of Jesus. Years later such 'lived experiences' of Jesus Christ were experienced by the Johannine community through the preaching ( $\mu \alpha \rho \tau$

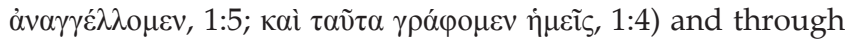
the written word of the Elder and the apostolic witnesses about the incarnation of the Son of God.

A second configuration of a spiritual 'lived experience ${ }^{\prime 62}$ was identified when it is assumed that first the Elder and then his adherents perceived who Jesus really was: the Word of life, the eternal life, the Son of God. ${ }^{63}$

The third configuration of a spiritual 'lived experience' was fellowship as existence in the family of God. The readers are called to experience fellowship with the divine corporately with the Elder and other witnesses. The nature of this fellowship is further spelled out by the Elder in the rest of the Epistle. All these 'lived experiences' should then converge or culminate in joy.

Finally, it also became evident how the Elder creates spiritual 'lived experiences' in the minds of the readers through devices such as the portrayal of Jesus' identity and dialectic language. The family metaphor creates another kind of spiritual experience. The use of certain words evokes experiences and can motivate people to act in a certain way.

\section{Acknowledgements Competing interests}

The author declares that he has no financial or personal relationship(s) which may have inappropriately influenced him in writing this article.

\section{References}

Adams, J., 1983, 'The familial image in rhetoric', Communication Quarterly 31(1), 56-61. http://dx.doi.org/10.1080/01463378309369486

Akin, D.L., 2001, 1, 2, 3 John, Broadman \& Holman, Nashville. (The New American Commentary, vol. 51, Logos Library System).

Berger, K., 2003, Identity and experience in the New Testament, Fortress Press, Minneapolis.

Brown, R.E., 1982, The epistles of John, Doubleday, Garden City.

Bultmann, R., 1973, The Johannine epistles, Fortress, Philadelphia. (Herder). PMCid:422915

Burger, G.K. \& Allen, J., 1973, 'Perceived dimensions of religious experience', Sociological Analysis 34(4), 255-264. http://dx.doi.org/10.2307/3709729

Carson, D.A., 1991, The Gospel according to John, W.B. Eerdmans, Grand Rapids.

Collins, K.J. (ed.), 2000, Exploring Christian spirituality, Baker Books, Grand Rapids.

Danker, F.W. (ed.), 2000, Greek English lexicon of the New Testament and other early Christian literature, 3rd edn., BDAG, Chicago.

Delling, G., 1979, ' $\alpha \rho \chi \omega, \kappa \tau \lambda$ ', in G. Kittel (ed.), Theological dictionary of the New Testament, vol. 1, pp. 478-489, Eerdmans, Grand Rapids.

De Vaux, R., [1961] 1973, Ancient Israel: Its life and institutions, Darton, Longman \& Todd, London.

Dodd, C.H., 1953, The Johannine epistles, Hodder and Stoughton, London. PMCid:2029778

Dunn, J.D.G., 1975, Jesus and the Spirit: A study of the religious and charismatic experience of Jesus and the first Christians as reflected in the New Testament SCM Press, London.

62. The difference between a physical lived experience and a spiritual lived experience is as follow: with a physical 'lived experience' a person experiences the physical is as follow. With a physical 'lived experience' a person experiences the physical presence of w whe believer perceives through faith a deeper meaning of the identity of the person which the
believer has seen physically: Jesus is the Son of God.

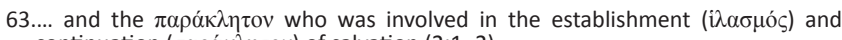

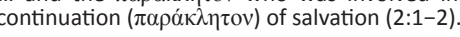


Du Rand, J.A., 1981, 'Studies in the Johannine Letters', Neotestamentica 13, 1-42.

Esler, P.F., 1997, 'Family imagery and Christian identity in Gal 5:13 to 6:10', in H. Moxnes (ed.), Constructing early Christian families: Family as social reality and metaphor, pp. 121-149, Routledge, London.

Esler, P.F., 2000, "Keeping it in the family": Culture, kinship and identity in 1 Thessalonians and Galatians', in J.W. van Henter \& A. Brenner (eds.), Families and family relations as represented in early Judaisms and early Christianities: Texts and fictions, pp. 145-184, Deo Pub, Leiden.

Graves, K., [1875] 2007, The world's sixteen crucified saviors: Christianity before Christ, Cosimo, New York.

Grayston, K., 1975, “'Logos” in 1 Jn 1', Expository Times 86(9), 279. http://dx.doi org/10.1177/001452467508600913

Gunkel, H., 1909, Die Wirkingen des Heiligen Geistes nach der popularen Anschauung der apostolischen Zeit und der Lehre des Apostels Paulus: eine biblischtheologische Studie, Vandenhoeck und Ruprecht, n.p.

Haas, C., De Jonge, M.D. \& Swellengrebel, J.L., 1972, A handbook on the letters of John United Bible Societies, New York. (9 UBS handbook series; Help for translators [11]).

Haas, C., De Jonge, M.D. \& Swellengrebel, J.L. 1994, A handbook on the letters of John United Bible Societies, New York. (UBS handbook series; Help for translators).

Hurtado, L.W., 2000, 'Religious experience and religious innovation in the New Testament', Journal of Religion 80, 183-205.

Hurtado, L.W., 2003, Lord Jesus Christ: Devotion to Jesus in early Christianity, Eerdmans, Grand Rapids.

Jackson, J.G., 1988, Pagan origins of the Christ myth, American Atheist Press, Austin.

Johnson, L.T., 1998, Religious experience in earliest Christianity: A missing dimension in New Testament studies, Fortress Press, Minneapolis.

Kruse, C.G., 2000, The letters of John, Eerdmans, Grand Rapids. (The Pillar New Testament Commentary).

Lieu, J.M., 1991, The theology of the Johannine Epistles, Cambridge University Press, Cambridge. http://dx.doi.org/10.1017/CBO9780511621376

Lombaard, C., 2008a, 'What is biblical spirituality? - Perspectives from a mino genre of Old Testament scholarship', in H. Blommestijn, C. Caspers, R. Hofman, F. Mertens, P. Nissen \& H. Welzen (eds.), Seeing the seeker: Explorations in the discipline of spirituality (Festschrift for Kees Waaijman; Studies in Spirituality discipline of spirituality (Festschrift for
suppl. 19), pp. 139-53, Peeters, Louvain.

Lombaard, C., 2008b, 'What is Biblical spirituality? - Perspectives from a minor genre of Old Testament scholarship', Journal of Theology for South Africa 135, 85-99.

Louw, J.P. \& Nida, E.A., 1996, Greek-English lexicon of the New Testament based on semantic domains, vol. 1, United Bible Societies, New York.

Marshall, I.H., 1978, Epistles of John, Eerdmans, Grand Rapids.

Margolis, R.D. \& Elifson, K.W., 1979, 'A typology of religious experience', Journal for the Scientific Study of Religion 18(1), 61-67. http://dx.doi.org/10.2307/1385379

Nabarz, P., 2005, The mysteriesa of Mithras: The pagan belief that shaped the Christian world, Inner Traditions, Rochester.

Osborn, M., 1967, 'Archetypal metaphor in rhetoric', Quarterly Journal of Speech 53, 115-126. http://dx.doi.org/10.1080/00335636709382823

Painter, J., 2002, 1, 2, and 3 John, The Liturgical Press, Collegeville.
Principe, W., 2000, 'Toward defining spirituality', in K.J. Collins (ed.), Exploring Christian spirituality, pp. 43-60, Baker Books, Grand Rapids.

Rusam, D., 1993, Die Gemeinschaft der Kinder Gottes: Das Motiv der Gotteskindschaft und die Gemeinden der johanneischen Briefe, Verlag W. Kohlhammer, Stuttgart.

Scheldrake, P., 2000, 'What is spirituality?', in K.J. Collins (eds.), Exploring Christian spirituality, pp. 21-42, Baker Books, Grand Rapids.

Schnackenburg, R., 1992, The Johannine epistles: Introduction and commentary, Crossroad, New York.

Schneiders, S.M., 2002, 'Biblical spirituality', Interpretation 56(2), 133-142. http:// dx.doi.org/10.1177/002096430005600202

Smalley, S.S., 1978, John: Evangelist and interpreter, Paternoster Press, Exeter.

Smalley, S.S., 2002, 1, 2, 3 John, Word, Incorporated, Dallas. (Word Biblical Commentary, vol. 51).

Smith, M., 1951, Tannaitic parallels to the Gospels, SBL, Philadelphia.

Smith, M., 1978, Jesus the magician, Gollancz, London.

Stark, R., 1965, 'Taxonomy of religious experience', Journal for the Scientific Study of Religion 5(1), 97-116. http://dx.doi.org/10.2307/1384259

Thomas, J.C., 2004, A Pentecostal commentary on 1 John, 2 John, 3 John, The Pilgrim Press, Cleveland.

Thompson, M.M., 2001, The God of the Gospel of John, Eerdmans, Grand Rapids.

Tollefson, K.D., 1999, 'Certainty within the fellowship: Dialectical discourse in 1 John', Biblical Theology Bulletin 29, 79-89.

Van der Merwe, D.G., 2005, 'Understanding "sin" in the Johannine epistles', Verbum et Ecclesia 26(2), 543-570. http://dx.doi.org/10.4102/ve.v26i2.240

Van der Merwe, D.G., 2006a, "A matter of having fellowship": Ethics in the Johannine epistles', in J.G. van der Watt (ed.), Identity, ethics, and ethos in the New Testament, pp. 535-563, Walter de Gruyter, Berlin. http://dx.doi. org/10.1515/9783110893939.535

Van der Merwe, D.G., 2006b, “'Having fellowship with God" according to 1 John. Dealing with the intermediation and envirionment through which and in which it is constituted', Acta Theologica Supplementum 8, 165-192.

Van der Merwe, D.G., 2009, 'Family metaphorics: A rhetorical tool in the epistle of 1 John', Acta Patristica et Byzantina 20(1), 89-108.

Van der Merwe, D.G., 2012, 'Those who have been born of God do not sin, because God's seed abides in them - sotheriology in 1 John', HTS Teologiese Studies/ Theological Studies 68(1), 1099-1109. ttp://dx.doi.org/10.4102/hts.v68i1.1099

Van der Watt, J.G., 1999, 'Ethics in First John: A literary and socioscientific perspective', Catholic Biblical Quarterly 61, 491-511.

Van der Watt, J.G., 2000, Family of the king: Dynamics of metaphor in the Gospe according to John, Brill, Leiden. PMid:11028222

Walls, D. \& Anders, M., 1999, I \& II Peter, I, II \& III John, Jude, Broadman \& Holman, Nashville. (Holman New Testament Commentary, vol. 11).

Weir, J.E., 1975, 'The identity of the Logos in the first epistle of John', Expository Times $86,118-20$.

Westcott, B.F., [1883] 1982, The epistles of St. John: Johannine studies since Westcott's day by F.F. Bruce, Eerdmans, Grand Rapids. 